\title{
ANALISIS STILISTIKA PADA LIRIK LAGU ALBUM JUMPING CAR OLEH HEY! SAY! JUMP
}

\author{
Ayu Rini Khoirunnisa*, Idah Hamidah, Hartati \\ Program Studi Sastra Jepang, Universitas Jenderal Soedirman, Purwokerto, Indonesia
}

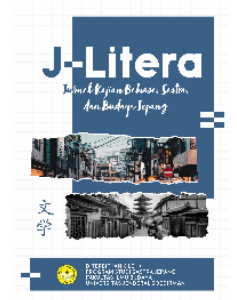

\begin{abstract}
This research examines the style of language in song lyric entitled "A Stylistic Analysis of Hey! Say! Jump's Song Lyrics in Jumping Car Album". This research aims to find out the kinds of language style and describe the meaning of the song lyrics. Language style theory used in this research is theory proposed by Keraf. This research used a descriptive research with qualitative approach. The data collection technique employed in this research was listening and note taking technique. Collected data were analyzed by using equivalent technique and technique of immediate constituent analyst. Data source used in this research is twelve song lyrics in Jumping Car album. The kinds of language style found consists of 3 (three) metaphor, 5 (five) personification, 7 (seven) simile, 16 (sixteen) allegory, 1 (one) eponym, 1 (one) synecdoche, 4 (four) metonymy, 1 (one) epithet, 1 (one) antonomasia, 1 (one) cynicism and 1 (one) sarcasm. The dominant kinds of language in this research is allegory. All of the meaning of the kinds of language which found shows songs in Jumping Car album describing love and life story in which contain happiness and sadness.
\end{abstract}

Keywords:

Song lyric: language style;

Hey! Say! Jump; Jumping Car

Article Info:

First received:

16 November 2019

Available online:

29 May 2020

\section{PENDAHULUAN}

Bahasa adalah alat yang digunakan manusia untuk berinteraksi dengan tujuan menyampaikan pikiran, gagasan, atau perasaan. Menurut Kridalaksana (2009:24) bahasa adalah sistem lambang bunyi yang digunakan oleh para anggota kelompok masyarakat untuk bekerja sama, berinteraksi, dan mengidentifikasi diri. Bahasa memiliki peranan yang sangat penting sebagai alat komunikasi dalam kehidupan manusia. Pada dasarnya, bahasa memiliki fungsi-fungsi tertentu yang digunakan berdasarkan kebutuhan seseorang, yakni sebagai alat untuk mengekspresikan diri, sebagai alat untuk berkomunikasi, sebagai alat untuk mengadakan integrasi dan beradaptasi sosial dalam lingkungan atau situasi tertentu, dan sebagai alat untuk melakukan kontrol sosial (Keraf, 1997: 3). Bahasa sebagai alat komunikasi ialah penyampaian pesan atau makna kepada orang lain.

Dalam ilmu linguistik, kajian makna dipelajari dalam ilmu semantik. Semantik adalah suatu bagian struktur bahasa yang berhubungan dengan makna ungkapan dan juga dengan struktur makna suatu wicara (Kridalaksana, 2009:216). Semantik memiliki hubungan erat dengan kehidupan manusia karena bahasa yang digunakan manusia sebagai alat komunikasi harus memiliki makna yang tepat agar mitra tutur dapat memahami pesan yang disampaikan. Makna bahasa tidak terlepas dari gaya bahasa, gaya bahasa seseorang sangat berpengaruh pada makna dari ungkapan seseorang tersebut.

Menurut Aminuddin (1995:5) gaya adalah cara yang dilakukan pemakai bahasa dalam memaparkan gagasan dan pikiran sesuai dengan tujuan dan efek yang ingin disampaikan. Gaya bahasa dalam linguistik disebut stilistika. Menurut Kridalaksana (2009:227) dalam Kamus Linguistik, stilistika adalah ilmu yang menyelidiki bahasa yang dipergunakan dalam karya sastra. Gaya bahasa atau yang biasa disebut majas merupakan cara penyampaian bahasa atau alat komunikasi yang tidak langsung kepada makna yang sebenarnya oleh pemakai bahasa untuk menyampaikan pemikirannya lewat kiasan atau ragam bahasa yang dipilih sehingga menimbulkan kesan tertentu. Gaya bahasa adalah cara mengungkapkan pikiran melalui 
bahasa yang khas untuk memperlihatkan jiwa dan kepribadian penulis (pemakai bahasa). Ada tiga unsur yang terkandung dalam suatu gaya bahasa yang baik yakni: kejujuran, sopansantun, dan menarik (Keraf, 2009:113).

Gaya bahasa dalam bahasa Jepang disebut 比喻 hiyu (Taniguchi, 2004:168). Banyak terdapat gaya bahasa di dalam karya sastra seperti novel, puisi, lirik lagu dan lain sebagainya. Manusia mempunyai bakat yang terkandung dalam gennya untuk mengembangkan berbagai macam perasaan, hasrat, nafsu serta emosi dalam kepribadian individunya, tetapi wujud dan pengaktifan dari berbagai macam isi kepribadiannya itu sangat dipengaruhi oleh berbagai macam stimulus yang berada dalam sekitar alam dan lingkungan sosial maupun budayanya (Koentjaraningrat, 1986:228).

Penelitian ini menggunakan lirik-lirik lagu Hey! Say! Jump dalam album Jumping Car sebagai sumber data. Hey! Say! Jump adalah idol group asal Jepang yang dibentuk pada tahun 2007 oleh Johnny \& Associates, Johnny Kitagawa. Saat ini Hey! Say! Jump beranggotakan 9 (sembilan) orang dengan 1 (satu) orang mantan anggota. Sampai saat ini Hey! Say! Jump telah merilis 21 (dua puluh satu) single dan 5 (lima) album. Salah satu albumnya berjudul Jumping Car dirilis pada tanggal 24 Juni 2015 yang di dalamnya terdapat 17 (tujuh belas) lagu dan 1 (satu) instrumental. Peneliti menggunakan 12 (dua belas) lagu pada album Jumping Car sebagai sumber data karena sudah mewalikili gaya bahasa yang akan diteliti. Lirik lagu yang akan dijadikan sumber data terdiri atas: Jumping Car, Walk, Weekender, Kira Kira Hikare, Ai yo Boku o Michiibite Yuke, Dangerous, Chau, Yowamushi Shooter, Farewell, 3 Gatsu 14 Nichi, Pet Shop Love Motion, dan Puppy Boo. Semua lirik lagu yang akan dijadikan sumber data pada album Jumping Car berbahasa Jepang. Penelitian ini diharapkan dapat memberikan manfaat terhadap pembelajar bahasa Jepang khususnya tentang gaya bahasa.

\section{LANDASAN TEORI}

\section{Lirik Lagu}

Kata dalam lagu adalah lirik. Menurut Kamus Besar Bahasa Indonesia (2016), lirik adalah susunan kata suatu karya sastra yang berisi curahan perasaan pribadi maupun orang lain yang dituangkan dalam tulisan. Lagu adalah suatu karya sastra yang digunakan untuk berkomunikasi secara langsung maupun tidak langsung. Lagu merupakan salah satu media hiburan yang pada setiap lirik lagu memiliki arti tersendiri, pesan yang disampaikan oleh penulis lirik lagu.

Kata-kata yang menyusun lirik lagu biasanya mengandung gaya bahasa yang bertujuan untuk memperindah, dan berkaitan dengan pemilihan kata-kata untuk mewaliki perasaan atau pesan yang disampaikan penulis lagu.

\section{Semantik}

Ada dua cabang utama linguistik yang khusus menyangkut kata yaitu etimologi, studi tentang asal usul kata, dan semantik atau ilmu makna, studi tentang makna kata (Ulmann, 2007:1). Menurut Sutedi (2014:127) sendiri semantik atau imiron (意味論) adalah cabang linguistik atau gengogaku (言語学) yang mengkaji tentang makna. Peranan semantik sangat penting karena bahasa yang digunakan dalam komunikasi bertujuan untuk menyampaikan suatu makna kepada mitra tutur.

Objek kajian semantik yaitu makna kata, relasi makna, makna frase, dan makna kalimat. Semua objek kajian semantik merupakan persoalan dari gaya bahasa yang akan menjadi fokus penelitian ini.

\section{Stilistika}

Stilistika adalah kajian tentang gaya, yaitu cara-cara yang khas, bagaimana sesuatu diungkapkan dengan cara tertentu, sehingga tujuan yang dimaksudkan dapat dicapai secara maksimal (Ratna, 2016:3). Kajian stilistika memiliki anggapan bahwa bahasa dari sebuah teks mencerminkan dunia tekstual secara sempurna karena seseorang memiliki cara pandang yang berbeda paling tidak secara fragmentaris oleh bahasa yang digunakan. Sebuah kajian linguistik bertujuan untuk mengungkapkan makna, yang mana makna dipandang sebagai sebuah hasil dari proses penafsiran (Black, 2011:1).

\section{Gaya Bahasa}

Keraf (2009:112) mengemukakan bahwa gaya atau khususnya gaya bahasa dikenal dalam retorika dengan istilah style. Kata style 
diturunkan dari kata Latin stilus, yaitu semacam alat untuk menulis pada lempengan lilin. Keahlian menggunakan alat ini akan mempengaruhi jelas tidaknya tulisan pada lempengan tadi. Kelak pada waktu penekanan dititikberatkan pada keahlian untuk menulis indah, maka style lalu berubah menjadi kemampuan dan keahlian untuk menulis atau mempergunakan kata-kata secara indah.

Trope atau figure of speech yang merupakan istilah lain atas gaya bahasa berdasarkan langsung tidaknya makna, yaitu apakah acuan yang dipakai masih mempertahankan makna denotatifnya atau sudah ada penyimpangan. Bila acuan yang digunakan masih mempertahankan makna dasar, maka bahasa itu masih bersifat polos. Jika sebaliknya, maka acuan tersebut dianggap sudah memiliki gaya bahasa yang dimaksudkan di sini. Keraf (2009:129) membagi gaya bahasa menjadi dua kelompok yaitu gaya bahasa retoris dan gaya bahasa kiasan.

\section{Gaya Bahasa Retoris}

Gaya bahasa retoris merupakan penyimpangan dari susunan dasar untuk mencapai kesan tertentu. Terdapat macammacam gaya bahasa retoris (Keraf, 2009:130), yaitu:

\section{(1) Aliterasi}

Aliterasi adalah semacam gaya bahasa yang berwujud perulangan konsonan yang sama. Biasanya digunakan dalam puisi, terkadang dalam prosa untuk perhiasan atau untuk penekanan.

Contoh: Senang susah sehidup semati.

\section{(2) Asonasi}

Asonasi adalah semacam gaya bahasa yang berwujud perulangan bunyi vocal yang sama. Biasaya digunakan dalam puisi, terkadang dalam prosa untuk memperoleh kesan penekanan atau sekadar keindahan.

Contoh: Di depannya kau menangis tersedusedu tak tahu malu.

\section{(3) Anastrof}

Anastrof atau inversi adalah semacam gaya retoris yang diperoleh dengan pembalikan susunan kata yang biasa dalam kalimat.
Contoh: Ditinggalkanlah ia tanpa tahu siapa ayah ibunya.

\section{(4) Apofasis}

Apofasis atau yang dapat juga disebut preterisio merupakan sebuah gaya di mana penulis atau pengarang menegaskan sesuatu, tetapi seperti menangkal. Berpura-pura menyembunyikan sesuatu, tetapi sebenarnya memamerkannya.

Contoh: Saya tidak mau menunjukkan kepadamu kalau saya baru saja membeli mobil baru.

\section{(5) Apostrof}

Apostrof adalah semacam gaya yang berbentuk pengalihan pesan dari para hadirin kepada sesuatu yang tidak hadir.

Contoh: Hai kamu arwah istriku, datanglah dan tunjukkanlah wujudmu.

\section{(6) Asindeton}

Asindeton adalah suatu gaya bahasa yang merupakan acuan, bersifat padat di mana beberapa kata, frasa, atau klausa yan sederajat tidak dihubungkan dengan kata sambung. Bentuk-bentuk itu biasanya dipisahkan dengan koma.

Contoh: Jiwon, Namil, Dongman adalah sahabat.

(7) Polisindeton

Polisindeton merupakan suatu gaya kebalikan dari sindeton. Beberapa kata, frasa, atau klausa yang berurutan dihubungkan satu sama lain dengan kata-kata sambung.

Contoh: Untuk dapat diterima di sekolah ini memerlukan semangat dan biaya yang sangat banyak serta membutuhkan kemampuan yang tinggi.

\section{(8) Kiasmus}

Kiasmus merupakan semacam acuan atau gaya bahasa yang terdiri dari dua bagian, baik frasa atau klausa, yang sifatnya berimbang, dan dipertentangkan satu sama lain, namun susunan frasa atau klausanya itu terbalik bila dibandingkan dengan frasa atau klausa lainnya. Contoh: Semangatku sudah hilang karenanya, lenyaplah semua impianku.

(9) Elipsis

Ellipsis adalah suatu gaya yang menghilangkan suatu unsur dalam kalimat 
yang dengan mudah dapat diisi atau ditafsirkan sendiri oleh pembaca atau pendengar.

Contoh: Jika nyawaku dicabut kamu pasti akan

\section{(10) Eufemismus}

Eufemismus sebagai gaya bahasa merupakan semacam acuan berupa ungkapanungkapan yang tidak menyinggung perasaan orang, atau ungkapan-ungkapan halus yang digunakan untuk menggantikan acuan yang mungkin dirasa menghina.

Contoh: Ibunya telah dipanggil yang maha kuasa.

\section{(11) Litotes}

Litotes adalah semacam gaya bahasa yang dipakai untuk menyatakan sesuatu dengan tujuan merendahkan diri, kurang dari keadaan sebenarnya, atau suatu pikiran dinyatakan dengan menyangkal lawan katanya.

Contoh: Kami hanya membawa sedikit oleholeh untukmu.

\section{(12) Histeron Proteron}

Histeron proteron merupakan gaya bahasa kebalikan dari sesuatu yang logis. Misalnya menempatkan sesuatu yang terjadi kemudian pada awal peristiwa.

Contoh: Buku ini akan memberikan sebuah kedamaian kepadamu.

\section{(13) Pleonasme dan Tautologi}

Pleonasme dan tautologi pada dasarnya adalah acuan yang menggunakan kata-kata yang lebih banyak daripada yang diperlukan. Suatu acuan disebut pleonasme apabila kata yang berlebihan itu dihilangkan, artinya tetap utuh. Sebaliknya, acuan disebut tautologi apabila kata yang berlebihan itu memiliki perulangan dari sebuah kata yang lain.

Contoh pleonasme: Darah dengan derasnya keluar dari hidung dan melumuri bagian atas mulut akibat dihantam sebuah bola kaki.

Contoh tautologi: Handphone bukan bulat bentuknya.

\section{(14) Perifrasis}

Perifrasis merupakan gaya yang mirip dengan pleonasme. Letak perbedaannya dalam hal bahwa kata-kata yang berkelebihan itu sebenarnya dapat diganti dengan satu kata saja. Contoh: Dia menjadi yang terbelakang di kelas ini.
(15) Prolepsis

Prolepsis atau antisipasi merupakan semacam gaya bahasa di mana orang mempergunakan lebih dahulu kata-kata sebelum peristiwa atau gagasan yang sesungguhnya terjadi.

Contoh: Ia berdiri tepat di samping calon pencuri dompetnya.

\section{(16) Erotesis}

Erotesis atau yang biasa disebut pernyataan retoris adalah semacam pertanyaan yang tidak membutuhkan jawaban. Biasanya digunakan dalam pidato atau tulisan.

Contoh: Jika ayah dan ibu meninggal, apakah kakak yang akan menanggung hidup adikadiknya?

\section{(17) Silepsis dan Zeugma}

Silepsis dan zeugma adalah gaya di mana orang mempergunakan dua susunan rapatan dengan menghubungkan sebuah kata dengan dua kata lain yang sebenarnya hanya salah satunya yang berhubungan dengan kata pertama. Silepsis menggunakan susunan secara gramatikal benar, tetapi secara semantik tidak benar.

Contoh: Ide dan dompetnya telah dicuri orang lain.

Sedangkan dalam zeugma kata yang dipakai untuk membawahi kedua kata berikutnya yang sebenarnya hanya cocok untuk salah satu daripadanya baik secara logis maupun gramatikal.

Contoh: Dengan menegaskan sikap dan matanya, ia membimbing anak-anak itu.

\section{(18) Koreksio atau Epanortosis}

Koreksio atau epanortosis adalah suatu gaya yang awal mulanya menegaskan sesuatu tetapi berujung dengan memperbaikinya.

Contoh: Saya hafal semua jalan tikus yang ada di daerah ini Karena saya sudah melewatinya sekitar tiga kali, maksud saya sekitar lima kali.

\section{(19) Hiperbol}

Hiperbol adalah suatu gaya bahasa yang memberikan pernyataan dengan melebihlebihkannya. Contoh: Dia adalah orang yang baik hati dan tulus kepada semua makhluk seperti Cinderella. 
(20) Paradoks

Paradoks merupakan semacam gaya bahasa yang mengandung pertentangan yang nyata dengan fakta yang ada.

Contoh: Saya pernah memiliki teman yang sebenarnya adalah musuh dalam selimut.

\section{(21) Oksimoron}

Oksimoron berasal dari kata okys yaitu tajam dan moros yang berarti gila. Oksimoron adalah gaya bahasa yang mengandung pertentangan dengan menggunakan kata-kata dalam frasa yang sama.

Contoh: Sifatnya tegas tetapi banyak yang membenci.

\section{Gaya Bahasa Kiasan}

Gaya bahasa kiasan mulanya dibentuk berdasarkan perbandingan atau persamaan. Membandingkan sesuatu dengan suatu hal yang lain, berarti mencoba menemukan ciri-ciri yang menunjukkan kesamaan antara kedua hal tersebut. Perbandingan sebenarnya memiliki dua pengertian, yaitu perbandingan yang termasuk dalam gaya bahasa yang polos atau langsung, dan perbandingan yang termasuk dalam gaya bahasa kiasan. Terdapat beberapa macam gaya bahasa kiasan (Keraf, 2009:136), yaitu:

\section{(1) Metafora}

Metafora merupakan gaya bahasa yang membandingkan dua hal secara langsung, tetapi dalam bentuk singkatnya.

Contoh: Suaranya memecah belah kesunyian.

\section{(2) Persamaan atau Simile}

Gaya bahasa persamaan atau yang biasa disebut simile adalah perbandingan yang bersifat eksplisit, yaitu langsung menyatakan sesuatu sama dengan hal yang lain. Maka dari itu, diperlukan upaya yang secara eksplisit menunjukkan kesamaan, yaitu kata-kata: sebagai, seperti, bagaikan, sama, laksana, dan sebagainya.

Contoh: Matanya terlihat bersinar seperti bintang di malam hari.

\section{(3) Personifikasi}

Personifikasi atau prosopopoeia adalah gaya bahasa kiasan yang menggambarkan bendabenda mati seolah-olah memiliki sifat-sifat kemanusiaan.

Contoh: Buah durian melindungi dirinya dengan duri.
(4) Alegori, Parabel, dan Fabel

Alegori adalah suatu cerita singkat yang mengandung kiasan. Parabel adalah suatu kisah singkat dengan tokoh-tokoh yang biasanya manusia yang mengandung tema moral. Sedangkan fabel adalah suatu metafora berbentuk cerita mengenai dunia binatang, di mana binatang bahkan makhluk-makhluk yang tidak bernyawa bertindak seolah-olah manusia.

\section{(5) Alusi}

Alusi merupakan semacam acuan yang berusaha mensugestikan kesamaan antara orang, tempat, atau kejadian. Alusi ini adalah suatu referensi yang eksplisit atau implisit kepada peristiwa, tokoh, atau tempat pada kehidupan nyata, mitologi, atau karya-karya sastra yang banyak dikenal.

Contoh: Yoona kecil selalu berlatih untuk mencapai impiannya.

\section{(6) Eponim}

Eponim adalah suatu gaya di mana nama dari seseorang sering dihubungkan dengan sifat tertentu, sehingga nama itu dipakai untuk menyatakan sifat tersebut.

Contoh: Teruslah berlatih menyanyi dan menari, maka kau akan menjadi Michael Jackson.

\section{(7) Sinekdoke}

Sinekdoke adalah gaya bahasa figuratif yang mempergunakan sebagian dari suatu hal untuk menyatakan keseluruhan ataupun sebaliknya. Comtoh: Tuan rumah digelarnya final bulutangkis harus menerima kekalahan dengan skor 2-3.

\section{(8) Metonimia}

Metonimia adalah gaya bahasa yang menggunakan sebuah kata untuk menyatakan suatu hal yang lainnya, karena mempunyai hubungan yang sangat dekat.

Contoh: Saya makan satu piring, ia tiga piring.

(9) Epitet

Epitet adalah gaya bahasa yang menyatakan suatu sifat atau ciri khusus dari seseorang atau suatu hal.

Contoh: Lonceng pagi untuk ayam jantan.

(10) Antonomasia

Antonomasia merupakan bentuk khusus dari sinekdoke dalam penggunaan sebuah epiteta 
untuk menggantikan nama diri, gelar resmi atau jabatan.

Contoh: Calon presiden nomor satu melakukan blusukan ke beberapa daerah.

\section{(11) Hipalase}

Hipalase adalah gaya bahasa di mana sebuah kata tertenu dipakai untuk menjelaskan sebuah kata, yang sebenarnya harus dipakai pada sebuah kata yang lain.

Contoh: Ia selalu memandangi lukisan yang tersenyum.

\section{(12) Ironi, Sinisme dan Sarkasme}

Ironi atau sindiran adalah gaya bahasa yang digunakan untuk menyampaikan suatu makna yang sebenarnya mempunyai maksud lain dari apa yang terkadnug dalam rangkaian katakatanya. Sedangkan sinisme diartikan sebagai suatu sindiran yang berwujud kesangsian yang mengandung ejekan terhadap keikhlasan dan ketulusan hati. Sarkasme lebih kasar dari ironi dan sinisme, mengandung celaan yang sangat pahit.

\section{(13) Satire}

Satire merupakan ungkapan untuk menertawakan atau menolak sesuatu. Bentuk satire tidak harus selalu berbentuk ironis, karena tujuannya adalah agar dilakukannya perbaikan secara etis maupun estetis.

\section{(14) Inuendo}

Inuendo adalah bentuk sindiran dengan mengecilkan kenyataan yang sesungguhnya. Contoh: Setiap kali diberikan tugas menjahit, ia selalu stress karena tidak bisa menjahit.

\section{(15) Antifrasis}

Antifrasis merupakan semacam ironi yang berwujud penggunaan sebuah kata dengan makna kebalikannya, dapat dianggap sebagai ironi sendiri atau kata-kata yang dipakai untuk menangkal kejahatan, roh jahat, dan sebagainya.

Contoh: Engkau memang orang yang mulia dan terhormat.

\section{(16) Pun atau Paronomasia}

Pun atau paronomasia adalah gaya bahasa kiasan yang menggunakan kemiripan bunyi. Contoh: "Pasti tugasmu sudah selesai!" "Ya. Selesai dalam mimpi!".

\section{PEMBAHASAN}

\section{Gaya Bahasa Metafora}

1) もし 100 万回君に「アイシテル」を届けてもつ いに君が僕に「YES」をくれなくてもまた 100 万回君に「アイシテル」を届けにゆこう愛よ、 僕を導いてゆけ

Moshi hyakumankai kimi ni "Aishiteru" o todoketemo

Tsui ni kimi ga boku ni "Yes" o kurenakutemo

Mata hyakumankai kimi ni "Aishiteru" o todoke ni yukou

Ai yo, boku o michibiite yuke

'Meski aku mengatakan aku mencintaimu berjuta kali pun

Pada akhirnya kau takkan berkata Ya

Mengatakan aku mencintaimu berjuta kali lagi Oh cinta, tuntunlah aku'

Bait lagu di atas mengandung gaya bahasa metafora yang terdapat pada kata 'Oh cinta'. Kata tersebut dapat digambarkan dengan sosok dewa cinta. Gambaran tersebut didukung oleh kalimat sebelumnya yaitu tokoh Aku yang putus asa mengerti dirinya akan ditolak meski menyatakan perasaannya berjuta kali lagi kepada orang yang dicintainya.

Dewa Cinta atau yang biasa disebut cupid bernama Eros berasal dari mitologi Yunani dan digambarkan dengan anak kecil yang membawa busur dan panah yang mana penggambaran tersebut sudah dikenal secara umum oleh manusia di bumi. Tentu sama halnya di Jepang, masyarakat Jepang juga mengenal Dewa Cinta. Dalam keyakinan Shinto yakni Benzaiten yang sama-sama memiliki arti 'Menyatukan dua insan untuk saling jatuh cinta', satu-satunya figur perempuan dalam 七福神 shicifukujin atau "Seven Gods of Fortune". Jadi makna dari gaya bahasa pada lirik lagu di atas adalah tokoh Aku mengharapkan pertolongan dari Dewa Cinta untuk membantunya membuat sosok yang dicintainya membalas perasaannya. Cintanya semakin dalam meski telah ditolak berkali-kali. Tokoh Aku akan terus berharap dan berjuang.

2）さあ始まりだ 太陽と Party time 時は Hey! Say! Jumpin' パラダイス サンシェイドも Cool 海岸線を Cruise キミを満たすまで帰さない 
Saa hajimari da taiyou to party time

Toki wa Hey! Say! Jumpin' paradaisu

Sansheido mo cool kaigansen o cruise

Kimi o mitasu made kaesanai

'Yeah waktunya berpesta dengan matahari dimulai

Hey! Katakan! Ini saatnya bersenang-senang di paradise

Bayangan matahari sangat indah saat kita berjalan di pesisir pantai

Tak akan melepasmu sampai kau puas'

Potongan lirik lagu Jumping Car tersebut memiliki gaya bahasa metafora di dalamnya, yakni kata "matahari" dan "paradise". Salah satu simbol dari matahari adalah kebahagiaan. Matahari dalam lirik lagu di atas dianalogikan sebagai wanita yang diajak berpesta oleh tokoh $\mathrm{Aku}$, wanita yang dapat memberikan kebahagiaan dengan cara bersenang-senang di tempat pesta bersama dengan hingar-bingar semangat, gairah dan kebahagiaan atau yang disebut dalam lirik lagu tersebut "paradise". Arti paradise secara harfiah ialah surga, memiliki arti yang sama dengan kata heaven. Berbeda dengan makna surga dari heaven yaitu surga yang ada di alam baka, surga dalam makna paradise ialah surga di dunia.

3) すぐに Kiss! Kiss! Kiss! 派手になってっ chau\#

デコレートされてく気持ち

騒げわいわいわい! 絶対終わらない

みんなが夢中 カーニバル

Sugu ni kiss! Kiss! Kiss! Hade ni nattecchau\#

Dekoreeto sareteku kimochi

Sawage wai wai wai! Zettai owaranai

Minna ga muchuu kaanibaru

'Ingin segera kiss! kiss! kiss! Jadi penuh warna

Perasaan yang diwarnai

Bergairah! Tak akan berakhir

Semua larut dalam pesta'

Kalimat di atas mengandung gaya bahasa metafora pada kata yang digaris bawahi. Kata "diwarnai" mempunyai persamaan kata dengan "dihias". Kata tersebut dapat diartikan kegiatan memperindah dengan memberikan sentuhan warna agar dapat lebih dinikmati seninya. Dalam hal ini, 'perasaan' bukanlah sebuah benda nyata, maka 'perasaan yang diwarnai' bermakna perasaan yang dibuat untuk merasakan sensasi bahagia dengan kecupan orang yang dicintai.

2. Gaya Bahasa Personifikasi

4）瞳が君を見つけたら僕らが始まる

繋いだ手に心まで伝わってく

時間の波にのまれても変わらない体温で

確かめ合うことが出来るよ

歩こうこのまま

Hitomi ga kimi o mitsuketara bokura ga hajimaru

Tsunaida te ni kokoro made tsutawatteku

Jikan no nami ni nomarete mo kawaranai taion de

Tashikameau koto ga dekiru yo

Arukou kono mama

'Saat pupilku menemukanmu, kisah cinta kita dimulai

Ikatan tangan menyentuh hati

Meski ditelan gelombang waktu dengan

keadaan yang sama

Bisa kupastikan

Jalani cinta kita seperti ini'

Gaya bahasa personifikasi terkandung dalam bait dari lirik lagu Walk di atas pada kalimat 'Saat pupilku menemukanmu' yang didukung oleh kalimat selanjutnya yakni 'Kisah cinta kita dimulai'. Pupil adalah bagian dari mata berupa lingkaran hitam sebagai sarana cahaya masuk ke dalam mata. Kata "pupil" bukanlah makhluk hidup yang bernafas ataupun bergerak dan dapat melakukan aktivitas layaknya manusia namun arti harfiah dari 'saat pupilku menemukanmu' seolah-olah pupil mencari tokoh Kamu dan berhasil menemukannya. Jadi makna sesungguhnya ialah saat Aku menatap mata Kamu muncullah rasa suka dan mulailah kisah cinta kita berdua.

Selanjutnya, kalimat 'Ikatan tangan menyentuh hati' juga mengandung gaya bahasa personifikasi. Makna Ikatan tangan bukanlah tangan yang diikat namun dua tangan yang saling menggenggam. Genggaman tangan dua orang yang sedang jatuh cinta dapat membuat hati terasa nyaman, yang dalam lirik lagu tersebut diungkapkan dengan kalimat ikatan tangan dapat menyentuh hati. Gaya bahasa personifikasi lain yang terkandung pada kalimat di atas ada pada baris ketiga kalimat 'Meski ditelan gelombang waktu'. Cinta (Mereka) yang ditelan gelombang waktu bermakna meskipun waktu terus bergulir, hari demi hari terus berganti dengan keadaan yang sama, saling mencintai, membuat tokoh Aku 
yakin dan berharap cinta mereka terus berlanjut.

\section{5） あの空に広がるいくつもの未来を} 君と僕で描いていたいいつでも

\section{Ano sora ni hirogaru ikutsu mo no mirai o \\ Kimi to boku de egaiteitai itsudemo}

'Langit mengisahkan kisah rahasia masa depan $\mathrm{Ku}$ ingin selalu melukis kisahku denganmu'

Lirik lagu di atas memiliki makna kiasan yang bertujuan untuk memperindah lirik lagu. Dalam lagu tersebut, langit seakan-akan bercerita layaknya manusia, dan hal ini termasuk dalam gaya bahasa personifikasi. Langit adalah ruang yang sangat luas tanpa ujung, banyak benda-benda di langit yang menggantung padanya. Oleh karena itu, langit hanya sebuah ruang hampa yang tidak dapat bercerita layaknya manusia.

\section{6）儚い夢に願いをかけて 眠るだけの恋が終わ り \\ 赤く摇らめく炎のような愛が 僕の目を覚ます}

Hakanai yume ni negai o kakete nemuru dake no koi ga owari

Akaku yurameku honoo no youna ai ga boku no me $\underline{\text { o samasu }}$

'Terlelap dengan harapan cinta yang tak jelas Cinta seperti api yang merah membara bisa membuka mataku'

Pada kalimat 'Cinta seperti api yang merah membara bisa membuka mataku' terdapat gaya bahasa personifikasi. Gaya bahasa tersebut menggambarkan benda-benda mati layaknya manusia; Seperti kata 'cinta' layaknya manusia yang dapat membuka matanya. "Cinta seperti api yang merah membara" dapat dimaknai sebagai perasaan hati yang sedang jatuh cinta dengan menggebugebu. Dalam lirik lagu tersebut tokoh Aku sedang dalam fase jatuh cinta, orang yang dicintainya adalah orang yang dapat membuatnya bersemangat jalani hidup, sehingga Ia sadar, bangkit dan berusaha untuk mendapatkan sumber semangatnya itu karena perasaan cintanya mata seseorang berbinar dan dapat pula menciptakan efek positif bagi dirinya, seperti perasaan senang dan bersemangat.

\section{7）夕暮れの街角 おかえりのハーモニー 心が躍りだす素敵な魔法さ}

\section{Yuugure no machikado okaeri ni haamonii \\ Kokoro ga odoridasu sutekina mahou sa}

'Harmoni di sudut jalan saat senja Hati mulai menari pada sihir yang indah'

Gaya bahasa personifikasi pada kalimat di atas tidak mengandung arti yang sebenarnya. Kata "hati" dalam hal ini, tidak mungkin bisa menari, karena "hati" bukanlah manusia yang bisa bergerak, melainkan salah satu organ tubuh manusia.

Senja adalah waktu pergantian dimana sore hari menjadi malam hari. Pada saat pergantian matahari dan bulan inilah langit terlihat begitu indah dengan warna-warna yang ditunjukannya, memberikan rasa kenyamanan dan kehangatan, inilah yang disebut dengan harmoni. Kata "sihir" dapat dimaknai dengan ketakjuban seseorang melihat dan merasakan suasana senja atau bisa juga disebut terhipnotis suasana senja. Maka kalimat yang mengandung gaya bahasa personifikasi tersebut memiliki makna hati yang mulai merasakan bahagia karena terhipnotis suasana di waktu senja.

8）全て見透かすように澄んだ君の瞳が罪深い この姿そっと映し出した 需れた夜の風が君の髪を撫でてむせるほど に甘い香り僕を狂わせるよ

Subete misukasu youni sunda kimi no hitomi ga tsumibukai kono sugata sotto utsushidashita

Nureta yoru no kaze ga kimi no kami o nadete museru hodo ni amai kaori boku o kuruwaseru yo

'Di bola mata indahmu tercermin sosok berdosa ini

Hembusan angin malam yang basah membelai rambutmu begitu manis hingga buatku menggila'

Bait dari lirik lagu di atas mengandung gaya bahasa personifikasi. Gaya bahasa tersebut menggambarkan benda mati bertindak seperti manusia yakni pada kalimat 'Hembusan angin malam yang membelai rambut'. Hembusan angin tidak dapat disamakan dengan manusia karena sesungguhnya hembusan angin tidak dapat membelai rambut.

Pada lirik lagu di atas digambarkan bahwa pada suatu malam mereka berdua berada di pinggir laut; mereka saling bertatapan 
sehingga muncullah sosok Aku yang tercermin dalam bola matanya. Tiba-tiba angin berhembus sehingga rambut wanita yang indah itu tertiup angin. Pada saat itulah seketika Aku menggila. Makna "menggila" dalam hal ini bukan gila karena gangguan jiwa, melainkan terpana akan wanitanya yang semakin mempesona saat rambut indahnya tertiup angin.

\section{Gaya Bahasa Simile}

9) 伏目がちな笑顔の後で急に君は大人びてし まうそれは鋭いナイフのように僕の胸を裂い $\tau<$

Fushime ga china egao no ato de kyuu ni kimi wa otonabite shimau

$\underline{\text { Sore wa surudoi naifu no youni boku no mune o }}$ saiteku

'Setelah kau menatap ke bawah dan tersenyum manis, tiba-tiba kau menjadi dewasa

Seperti pisau tajam yang membelah dadaku'

Pada kalimat yang mengandung gaya bahasa simile tentu terdapat kata pembanding yaitu bak, bagaikan, seperti, laksana, dan lain sebagainya. Pada data kesembilan ini ditandai dengan adanya kata youni yang memiliki makna 'seperti' yang merupakan kata pembanding pada kalimat 'Seperti pisau tajam yang membelah dadaku'.

Pada lirik lagu di atas pencipta lagu menceritakan tokoh Aku merasakan dadanya sakit seperti dibelah dengan pisau yang tajam karena tidak bisa menerima seseorang yang dicintainya tiba-tiba berubah menjadi dewasa. "Menjadi dewasa" dalam hal ini memiliki makna menjadi wanita dewasa tidak lagi berperilaku manis seperti anak remaja yang masih lucu. Jadi makna dari lirik lagu di atas adalah tokoh Aku mencintai seseorang yang sedang tersenyum manis layaknya anak remaja, terkejut karena setelah itu wanita yang dicintainya itu tumbuh menjadi dewasa; dewasa dalam hal penampilan dan perilaku. Hal ini berhubungan dengan psikologi tokoh $\mathrm{Aku}$, yang tidak bisa menerima perbedaan dalam hal itu dan terus ingin sama selamanya.

\section{0）言葉選ぶほどに 掛け違えたボタンのように逸 れてく 愛されたいわけじやない 君の全てを愛していた w}

Kotoba erabu hodo ni kake chigaeta botan no youni hagureteku

Ai saretai wake janai kimi no subete o aishite itai

'Seperti salah mengancingkan kancing baju perkataanku jadi menyakitkan

Tidak berarti aku tidak ingin dicintai namun aku ingin mencintaimu seutuhnya'

Lirik lagu di atas mengandung gaya bahasa simile. Gaya bahasa simile dalam lirik lagu ini ditandai dengan terdapatnya kata ように youni yang berarti 'seperti'. Kalimat "Seperti salah mengancingkan kancing baju" secara harfiah dimaknai dengan kegiatan mengancingkan baju yang tidak sesuai dengan lubang kancing baju dan hal itu tentu merupakan kesalahan. Baju menjadi tidak nyaman dipakai dan dipandang. Begitupun halnya jika kita berbicara tanpa memikirkan perasaan mitra bicara, itu merupakan kesalahan bahkan dapat menyakiti hatinya.

Situasi dalam lirik lagu ini dijelaskan pada bait sebelumnya saat tokoh Aku tidak dapat menerima keadaan saat orang yang dicintainya menjadi lebih dewasa dalam hal penampilan dan perilaku. Lalu dalam bait ini tokoh Aku melakukan kesalahan dalam perkataannya akan hal itu. Aku tersadar akan hal tersebut dan merasa menyesal, padahal seseorang yang dicintainya itu pun belum membalas cintanya. Agar ia tidak semakin menjauh dan sulit didapatkan, tokoh Aku menegaskan kalau ia ingin menjadi seseorang yang lebih mencintai.

11) Let's spend the time together forever

$$
\begin{aligned}
& \text { 僕らの愛がこの文字のように 時間を刻んでく } \\
& \text { ゆっくりと二の秒針が } \\
& \text { 寄り添い合いながら 愛を刻んでゆく } \\
& \text { あの日誓った 離さないって } \\
& \text { 来年のこの日も一緒にいようよ }
\end{aligned}
$$

Let's spend the time together forever

Bokura no ai ga kono moji no youni jikan o kizandeku

Yukkuri to futari no byoushin ga

Yorisoi ai nagara ai o kizande yuku

Ano hi chikatta hanasanaitte

Rainen no kono hi mo isshoni iyou yo

'Mari habiskan waktu bersama selamanya Cinta kita seperti angka yang terukir dalam $\underline{\text { waktu }}$ 
Perlahan kedua tangan kita

Mengukir cinta sambil berpelukan

Hari itu kita berjanji takkan berpisah

Tahun depan di hari yang sama masih tetap bersama'

Dalam lirik lagu di atas terkandung gaya bahasa simile yang membandingkan hal secara eksplisit dan ditandai dengan kata ように youni yang artinya 'seperti' pada baris kedua bait tersebut. Seperti yang sudah diungkapkan pada bait sebelumnya 'Di balik jam itu ada pesan untukmu', bait ini adalah pesan yang ada di balik jam tangan, untuk orang yang dicintai tokoh Aku.

Arti kata 文字 moji ialah karakter. Contoh karakter yaitu huruf dan angka. Karakter yang dimaksud dalam lirik lagu di atas adalah angka, angka yang ada pada waktu. Waktu adalah perjalanan peristiwa yang terjadi di masa lalu, masa sekarang dan masa depan. Waktu bersifat abadi, tidak ada batas. Waktu yang dimaksud dalam lirik lagu di atas dimaknai dengan alat yang digunakan untuk mengukur waktu yaitu jam. Jam terdiri dari angka dan jarum jam. Maka "Cinta kita seperti angka yang terukir dalam waktu" dapat dimaknai dengan perasaan mencintai dan menyayangi sepanjang waktu yang berarti tidak akan berakhir walaupun ada halangan di dalam perjalanannya. Ukiran dalam waktu tersebut dibuat dengan cara berpelukan. Makna "dengan cara berpelukan" ini adalah dengan terus saling mencintai.

\section{2) ダメだよユア・マイPuppy Boo 見えなくなる ほど離れちや 優しい首輪みたいに 手を繋いじゃうぞ}

Dame da yo yua mai Puppy Boo mienakunaru hodo hanarecha

\section{Yasashii kubiwa mitaini te o tsunaijauzo}

'Kaulah puppy boo ku, jangan pergi jauh dari pandanganku

Seperti rantai lembut yang akan menuntunmu'

Adanya kata みたいに mitaini yang mempunyai arti 'seperti' menunjukkan rangkaian kata di atas mengandung gaya bahasa simile. Kalimat tersebut dengan jelas membandingkan dua hal. Dua hal yang dibandingkan tersebut adalah 'ikatan' mereka berdua dan 'rantai'. Rantai digunakan untuk mengikat dan atau mengangkat barang yang berat. Dalam hal ini bukan rantai yang sebenarnya yang digunakan, namun rantai yang dimaknai dengan sikap atau perilaku yang dilakukan pada orang yang dicintainya agar merasa nyaman, dan aman. Hal tersebut dilakukan dengan cara selalu bersama saling menjaga dan menyayangi.

\section{3）吹き抜ける潮風のような 少ししょつぱい涙流 せたらいいさ}

\section{Fukinukeru shiokaze no youna sukoshi shoppai namida nagasetara ii sa}

'Tak apa meneteskan air mata asin seperti hembusan angin laut'

Kata ような youna pada kalimat di atas menandai adanya gaya bahasa simile yang menandai dua hal yang berbeda namun mempunyai sifat yang sama. Dua hal yang memiliki sifat yang sama adalah air mata dan hembusan angin laut.

Udara dibawa oleh angin, maka udara di sekitar laut dibawa oleh angin laut. Salah satu manfaat udara yang dibawa angin laut ialah dapat menyegarkan ataupun menenangkan pikiran dan hati, karena bersih, jauh dari polusi dan kebisingan seperti di perkotaan. Maka 'Tak apa meneteskan air mata asin seperti hembusan angin laut' dapat dimaknai bahwa tokoh Aku membiarkan seseorang untuk menangis agar perasaan hatinya menjadi lebih baik.

14) すぐに kiss! kiss! kiss! 恋しちゃって high

$$
\begin{aligned}
& \text { ピンボールみたいな気持ち } \\
& \text { 騒げ yeah! yeah! yeah!ドキドキの beat } \\
& \text { 君との出会いに セレブレイト }
\end{aligned}
$$

Sugu ni kiss! kiss! kiss! koishichatte high

Pinbooru mitaina kimochi

Sawage yeah! yeah! yeah! dokidoki no beat

Kimi to no deai ni serebureito

'Ingin segera cium! cium! cium! jatuh cinta lebih dalam

Perasaan bagai pinball

Buat bahagia yeah! yeah! yeah! tempo hati yang berdebar

Merayakan pertemuan denganmu'

Bait dari lirik lagu Chau di atas mengandung gaya bahasa simile. Salah satu kata yang merupakan ciri khas gaya bahasa simile terkandung dalam potongan lirik tersebut, yakni みたいな mitaina yang artinya 
ialah 'bagai'. Pinball adalah suatu permainan arkade yang ada di game center bahkan ada juga di perangkat lunak yang ada di komputer, gawai, dan lain sebagainya. Bola dalam permainan ini harus dikontrol agar tidak jatuh ke lubang. Bola itu terus terpantul-pantul pada benda di sekitar papan permainan ke atas, bawah, samping kanan, dan samping kiri.

Sama halnya dengan kalimat "Perasaan bagai pinball" pada lirik lagu di atas, perasaan itu mempunyai karakteristik yang sama dengan pinball yang naik-turun terlempar sana-sini yang dimaknai dengan perasaan hati yang berdebar membuat jantung berdegup kencang karena bertemu dengan seseorang yang membuatnya jatuh cinta.

15) 君の視線まるでレーザービーム目と目ビビッ とエレクトリック

シビれちやってうまく言えない今日も進展ナ ツシング no way!

Kimi no shisen marude reezaabiimu me to me bibitto erekutorikku

Shibirechatte umaku ienai kyou mo shinten nassingu no way!

'Tatapanmu seperti sinar laser, ada aliran listrik saat menatapmu

Oh tidak! Hari ini pun terdiam tak berkata

apapun tak ada kemajuan'

Potongan lirik lirik lagu di atas memiliki gaya bahasa simile yang membandingkan dua hal secara eksplisit, dan dijelaskan dengan kata penghubung まるで marude 'seperti' yang merupakan salah satu ciri khas gaya bahasa simile.

Tatapan adalah suatu proses melihat suatu objek yang sedang diperhatikannya. Dalam hal ini objek tatapannya adalah tokoh Aku yang mana tatapannya seperti sinar laser. Sinar laser tercipta karena cahaya yang bergerak ke arah yang sama dan memiliki tingkat kecerahan yang tinggi atau tajam. Sinar laser akan membuat mata sakit apabila cahayanya mengenainya. Hal itu menunjukkan karakteristik yang sama dengan makna dari "Tatapannya seperti sinar laser" yakni tatapannya yang tajam sehingga tokoh Aku hanya gugup terdiam tidak dapat berkata apaapa untuk mengutarakan rasa cintanya.

\section{Gaya Bahasa Alegori}

16) 君の心 哯き込めたらたったひとつ確かめて みたい君へ続く道のどこかに 僕はいるのか な

\section{Kimi no kokoro nozoki kometara tatta hitotsu} tashikamete mitai

Kimi e tsudzuku michi no doko ka ni boku wa iru no kana

'Bila aku dapat melihat isi hatimu, ku ingin mencoba memastikan satu hal Apakah diriku ada di jalan yang membawaku kepadamu'

Lirik lagu di atas mengandung gaya bahasa alegori karena tidak menggunakan arti yang sebenarnya. Kata "Hati" pada kalimat tersebut secara harfiah tidak bisa dilihat karena hati adalah salah satu organ manusia yang berfungsi atas keberlangsungan hidup manusia. Kata "Hati" disini dimaknai dengan perasaan yang dirasakan oleh seseorang yang dicintai oleh tokoh Aku. Tokoh Aku berharap untuk bisa mencoba memahami apa yang dia pikirkan dan dirasakan tentangnya. Dia pun bertanya-tanya apakah Ia ada di jalan yang membawanya kepada seseorang yang dicintainya yang dapat dimaknai dengan memastikan apakah seseorang itu juga mencintainya.

17) 儚い夢に願いをかけて 眠るだけの恋が終わ 赤く摇らめく炎のような愛が僕の目を覚ます

Hakanai yume ni negai o kakete nemuru dake no koi ga owari

Akaku yurameku honoo no youna ai ga boku no me o samasu

'Terlelap dengan harapan cinta yang tak jelas Cinta seperti api yang merah membara, bisa membuka mataku'

Lirik lagu di atasa muncul dalam lagu Ai yo michibiite yuke; di dalamnya terdapat gaya bahasa alegori karena menggunakan kata-kata kiasan untuk menyampaikan arti sesungguhnya. 儚い hakanai secara harfiah memiliki arti 'tidak stabil' yang dalam lirik lagu di atas dimaknai dengan 'tidak jelas', dan dikaitkan dengan 夢 yume yang berarti 'mimpi'. 'Mimpi' dalam hal ini bukan mimpi yang muncul dalam tidur, melainkan harapan 
atau keinginan seseorang akan sesuatu. 'Harapan' dalam lirik lagu ini adalah harapan tentang cinta yang tidak jelas.

Maka kalimat "Terlelap dengan harapan cinta yang tak jelas" dapat dimaknai dengan keadaan kisah cinta tokoh Aku yang berakhir dengan ketidakjelasan karena Ia tidak tahu apa yang dipikirkan dan dirasakan oleh sosok yang dicintainya tentang tokoh Aku, namun tidak melakukan hal apapun. Hingga semangat dalam dirinya muncul, lalu memutuskan untuk melakukan usaha yang lebih ekstra untuk mencapai harapannya.
18) 君のかじかむ手を温められるのが僕じやなく て僕の未来照らす人はこの世界で君だけだ よ

Kimi no kajikamu te o atatamerareru no ga boku janakute mo

Boku no mirai terasu hito wa kono sekai de kimi dake da yo

'Bukan aku yang menghangatkan tanganmu yang mati rasa karena kedinginan namun Hanya kaulah yang mampu menyinari masa depanku di dunia ini'

Kalimat di atas mengandung gaya bahasa alegori karena menggunakan kiasan.

Kalimat 'Bukan aku yang menghangatkan tanganmu yang mati rasa karena kedinginan' dimaknai dengan meskipun Aku tidak ada di sampingmu, kau tetap baik-baik saja. Makna tersebut didukung oleh pernyataan pada kalimat, bahwa bukan Aku lah yang menghangatkan tangannya yang kedinginan, karena pada saat terjadinya peristiwa itu, Aku tidak ada di sampingnya. Namun, hanya Kamu lah yang dapat menyinari masa depan Aku. Kata "Menyinari" dalam hal ini dimaknai dengan membuat semangat dan bahagia. Jadi, tokoh Kamu tetap akan baik-baik saja meski tidak bersama tokoh Aku. Sebaliknya, hidup tokoh Aku tidak akan berjalan dengan baik apabila tidak bersama tokoh Kamu akibat mencintai terlalu dalam.

19) You and I 妄想じやなくて Realize 触れてみ たいよ身体じゃなくてその心
衝動みたいな感情を制御出来ずに持て余し
て
目に見えない翼になる境界線超えて行ける

$\underline{\text { You and I mousou janakute }}$
Realize furete mitai yo karada janakute sono kokoro Shoudou mitai na kanjou o seigyo dekizu ni mote amashite

Me ni mienai tsubasa ni naru kyoukaisen koete yukeru

'Kau dan aku bukanlah ilusi

Ingin kusentuh hatimu bukan tubuhmu

Gairah yang tak bisa dikendalikan

Menjadi sayap yang tak terlihat oleh mata dan menembus batas'

Kata-kata kiasan yang digunakan pada lirik di atas menunjukkan gaya bahasa alegori sebab tidak secara langsung menjelaskan arti yang sebenarnya. "Ilusi" ialah khayalan, sesuatu yang tidak nyata adanya. Kemudian 心 kokoro dalam hal ini bukan organ ada yang pada tubuh manusia melainkan akal pikiran dan perasaan dalam jiwa manusia. Maka pada kalimat 'Kau dan aku bukanlah ilusi' dapat dimaknai dengan Tokoh Aku yang mempunyai perasaan cinta yang kuat akan seseorang yang dicintainya. Hal tersebut membuat anganangannya untuk bersatu bukanlah suatu khayalan yang mustahil dan dapat terjadi. Rasa optimis dari tokoh utama membuatnya tetap semangat dalam mencapai harapan.

Kemudian 'Ingin kusentuh hatimu bukan tubuhmu' dimaknai dengan keinginan untuk membuat Ia mencintainya juga. Keinginannya yang kuat tercermin dalam kalimat 'gairah yang tak bisa dikendalikan', lalu mengabaikan hal apapun yang menjadi penghalang untuk menyatukan cinta mereka yang tercermin dalam kalimat 'menjadi sayap yang tak terlihat oleh mata dan menembus batas'.

20) ひとりより強いふたりになっていける今が満ち

\section{Hitori yori tsuyoi futari ni natteikeru Ima ga michiteiku}

'Berdua lebih baik

Sekarang kita adalah satu'

Kalimat di atas mengandung gaya bahasa alegori karena mengungkapkan sesuatu menggunakan kata-kata kiasan yang bukan makna sebenarnya. Kalimat tersebut bisa dimaknai dengan keputusan menjadi pasangan dalam kehidupan suka dan duka sebab saling membutuhkan. Sejatinya manusia adalah makhluk ciptaan Tuhan yang tidak bisa lepas 
hubungannya dengan sesamanya. Seperti interaksi sosial, yang sangat berpengaruh pada psikologi manusia. Apabila tidak ada interaksi sosial, manusia akan merasa kesepian bahkan kesedihan yang memberikan efek negatif seperti depresi. Dengan melakukan interaksi sosial, manusia dapat merasakan ketenangan dan kenyamanan dalam dirinya dengan menceritakan apa yang dirasakan; contohnya kisah yang dialami tokoh $\mathrm{Aku}$ seperti cerita dalam lirik lagu di atas.

\section{1)あの空に広がるいくつもの未来を 君と僕で描いていたいいつでも}

Ano sora ni hirogaru ikutsu mo no mirai o Kimi to boku de egaiteitai itsudemo

'Langit mengisahkan kisah rahasia masa depan $\underline{\mathrm{Ku} \text { ingin selalu melukis kisahku denganmu' }}$

Gaya bahasa alegori terdapat pada kalimat di atas karena tidak menjelaskan makna yang sebenarnya namun dengan menggunakan kiasan. Kalimat ' $\mathrm{Ku}$ ingin selalu melukis kisahku denganmu' dapat dimaknai dengan keinginannya untuk terus bersama orang yang dicintainya menjalani kehidupan dalam suka maupun duka. Hal tersebut dapat didukung oleh uraian pembahasan tentang makna 'Langit mengisahkan kisah rahasia masa depan' pada data ke 5 (lima), yakni langit yang menjadi tempat bergantung benda-benda yang ada di langit seperti bintang, planet dan sebagainya maka tokoh utama pada cerita di atas juga ingin menggantungkan harapannya tersebut di langit.

22)瞳が君を見つけたら世界が輝く 君のッペースに合わせて少しゆっくり 流れていく景色の中 変わらない笑顔で 君のことを見つめていたいよ

歩こう 並んんで

Hitomi ga kimi o mitsuketara sekai ga kagayaku

Kimi no peesu ni awasete sukoshi yukkuri

Nagareteiku keshiki no naka kawaranai egao de

Kimi no koto o mitsumeteitai yo

Arukou narande

'Saat mataku menatapmu, dunia seakan

bersinar

$\underline{\text { Perlahan melangkah bersamamu }}$
Hanyut dalam suasana, dengan senyum yang

$\underline{\text { sama }}$

$\underline{\mathrm{Ku} \text { ingin memandangmu }}$

Sembari melangkah'

Lirik lagu di atas mengandung gaya bahasa alegori karena menggunakan kata-kata kiasan yang bertujuan untuk memperindah lirik. Menggambarkan saat-saat Aku menyadari bahwa "dunia seakan bersinar" yang bermakna kebahagiaan akan terus bersamanya apabila mereka berdua saling mencintai dan menyayangi. Mereka terus menjalani hari-hari penuh kasih sayang. Tokoh Aku pun mengutarakan "ingin terus memandangmu sembari melangkah" yang dimaknai bahwa Ia ingin keadaan ini terus berlangsung seiring kehidupan, saling mencintai dan menyayangi.

23) You're so dangerous, dangerous 一度触れ たら離れられない Your love is dangerous, dangerous そのぬくもりに溺れてくよ 溢れそうな愛しさに全てを忘れて Your love is dangerous, dangerous, dangerous 逃げられはしない Your love is dangerous

You're so dangerous, dangerous ichido furetara hanarerarenai

Your love is dangerous, dangerous sono nukumori ni oboreteku yo

Afuresouna itoshisa ni subete o wasurete

Your love is dangerous, dangerous, dangerous

nigerare wa shinai

Your love is dangerous

'Kau sangat berbahaya berbahaya berbahaya tak bisa dilepaskan

Cintamu berbahaya hampir tenggelam dalam kehangatan

Lupakan semua kasih sayang yang meluap-luap ini

Cintamu berbahaya berbahaya berbahaya tak bisa pergi Cintamu berbahaya'

Rangkaian kata di atas mengandung gaya bahasa alegori karena menerangkan sesuatu menggunakan kiasan. Kata dangerous "bahaya" adalah suatu hal yang dapat menyebabkan masalah. Pada penulisan lirik lagu yang berhubungan dengan cinta kata "bahaya" sering kali dikaitkan dengan sesuatu yang memiliki makna positif karena tokoh Aku menikmatinya. 
Seperti lirik di atas bahwa tokoh utama terjerat oleh cinta, hampir tenggelam dalam kehangatan. Maksud dari kalimat tersebut memiliki arti yang positif sebab dirinya dapat merasakan jatuh cinta akibat perlakuan baik yang diberikan oleh sosok yang Ia cintai. Perlakuan baik yang dilakukan dapat membuat tokoh Aku merasa disayang dan dicintai sehingga muncul perasaan nyaman dan bahagia. Tercermin pada kalimat "cintamu berbahaya berbahaya berbahaya tak bisa pergi" bahwa Ia sudah terlena oleh kasih sayang dan cinta yang didapatkannya.

24）空の外唍くと

$$
\begin{aligned}
& \frac{\text { 蕾がもう芽吹いて }}{\text { もうそそろプレゼント }} \\
& \text { 見つけに行かなきやね }
\end{aligned}
$$

Mado no soto nozoku to

Tsubomi ga mou mebuite

Mou soro soro purezento

Mitsuke ni ikanakyane

'Saat melihat keluar jendela

Bunga sudah mulai bermekaran

Saatnya musim hadiah

Aku harus mendapatkannya'

Gaya bahasa alegori terdapat pada lirik lagu di atas yang ditunjukkan dengan ungkapan 'Bunga sudah mulai bermekaran, saatnya musim hadiah' yang dibaliknya terdapat arti yang sebenarnya. Bunga bermekaran di Jepang dikenal dengan Sakura yang berlangsung pada saat musim semi, musim yang paling indah di antara musim-musim lainnya. Tujuh hari adalah waktu terindah sakura bermekaran. Mekarnya bunga sakura merupakan simbol kebahagiaan dan kehangatan bagi masyarakat Jepang. Kegiatan yang biasa dilakukan saat musim semi salah satunya adalah hanami, yakni kegiatan berkumpul dengan keluarga, kerabat, atau teman untuk menyaksikan sakura bermekaran dengan indah. Maka 'Bunga sudah mulai bermekaran' dapat dimaknai dengan penggambaran musim semi, yang mana 'saatnya musim hadiah' dapat dimaknai dengan waktunya penuh kebahagiaan seperti simbol bunga bermekaran itu sendiri bagi masyarakat Jepang.

25) 水平線の青いキャンバスに白く浮かぶ雲 波に乗せて弱虫な今を 遠くに飛ばせる気が

\section{$\underline{\text { Lた }}$}

Suiheisen no aoi kyanbasu ni shiroku ukabu kumo

Nami ni nosete yowamushi na ima o tooku ni tobaseru ki ga shita

'Kanvas biru yang tergores awan putih di kaki $\underline{\text { langit }}$

Di atas ombak melepas jiwa lemahku jauhjauh'

Gaya bahasa alegori ditunjukkan oleh penggunaan kata-kata kiasan pada kalimat 'Kanvas biru yang tergores awan putih di kaki langit, di atas ombak melepas jiwa lemahku jauh-jauh' yang bertujuan untuk memperindah lirik. Kata 青いキャンバス aoi kyanbasu "Kanvas biru" merupakan makna dari langit. Langit adalah suatu ruang yang sangat luas dan tidak memiliki ujung. "Langit yang tergores awan putih" adalah makna dari awan putih yang ada pada langit, sebab sejatinya langit adalah tempat bergantungnya benda-benda di langit. Awan putih dalam lirik di atas berada di horizon yang merupakan langit bagian bawah perbatasan permukaan bumi dan laut atau singkatnya dapat disebut kaki langit.

Penjelasan makna di atas dengan kalimat 'di atas ombak melepas jiwa lemahku jauh-jauh' dapat disimpulkan keseluruhan makna dengan lokasi kejadian berada di atas laut penuh ombak, tokoh utama sedang merenungi dirinya sambil memandang indahnya awan-awan yang ada di kaki langit yang mempengaruhinya berpikir positif untuk menghilangkan sifat-sifat dan perilaku buruknya untuk bangkit dari keterpurukan. Laut dengan lingkungannya memiliki sejuta keindahan dapat mempengaruhi seseorang untuk berpikir positif yang bermanfaat bagi kesehatan mental dan fisiknya.

\section{6）めまぐるしい時間の隙間に絡まってた欠片 探してる だから}

\section{Memagurushii jikan no sukima ni karamatteta kakera sagashiteru dakara}

'Dalam sesaknya waktu ku mencari bagian hatiku yang hancur'

Bait lagu di atas mengandung gaya bahasa alegori karena mengungkapkan suatu makna menggunakan kata-kata kiasan.

Kalimat "Dalam sesaknya waktu ku mencari bagian hatiku yang hancur" dapat 
dimaknai dengan keadaan seseorang yang terpuruk, lalu tersadar bahwa tidak boleh terusmenerus hidup seperti ini. Mengumpulkan tekad dan semangat untuk bangkit dari keadaan itu, karena semua hal akan berjalan dengan baik apabila dimulai dari kesadaran dan keinginan diri sendiri untuk tujuan yang baik pula.

27) 土砂振りの世界を抜けて

火のついた衝動 確かめるなら

辻䙅の合わない感情

容赦ない現実 戦うしかない

Doshaburi no sekai o nukete

Hi no tsuita shoudou tashikameru nara

Tsujitsuma no awanai kanjou

$\underline{\text { Youshanai genjitsu tatakau shikanai }}$

'Menampakkan diri dari derasnya hujan dunia

Bila dorongan dalam hati ini berapi-api

Pada perasaan yang tak konsisten

Yang bisa dilakukan hanyalah melawan

kenyataan yang pahit ini'

Potongan lirik lagu di atas memuat gaya bahasa alegori di dalamnya karena mengungkapkan suatu arti menggunakan kiasan yang memperindahnya. 土砂振り doshaburi 'hujan deras' ialah butiran cairan yang menetes dan jumlahnya sangat banyak dihasilkan oleh awan di langit yang disebabkan oleh uap air yang mengembun di atmosfer. Saat sampai di bumi cairan tersebut dapat berbentuk air, salju dan es. Lirik lagu ini menggunakan kata "derasnya hujan" yang menggambarkan suatu beban hidup yang sangat berat, menimbulkan rasa kesedihan dan keputusasaan yang berujung pada keterpurukan. Kata "berapi-api" adalah kata kiasan yang mempunyai makna suasana hati yang sangat bersemangat. Perasaan yang berapi-api biasanya disebabkan oleh dorongan besar untuk memenuhi keinginannya. Kata kiasan lain yang terdapat pada bait di atas adalah 'Pahit'. 'Pahit' ialah rasa yang tidak enak. Rasa pahit ada pada makanan atau minuman, yang cenderung tidak dapat memberikan sensasi yang menyegarkan setelah menyantapnya. Kata 'pahit' yang sering kali digunakan sebagai kiasan, menggambarkan suatu hal yang tidak menggembirakan atau menyedihkan. Keseluruhan makna di atas maka dapat disimpulkan makna dari bait di atas adalah tokoh Aku mulai berusaha bangkit dari keterpurukan dengan sangat semangat namun apabila tidak konsisten, maka teruslah nikmati hidup dengan kesedihan.

28) 思い切り Jumpin' up 叫んで 大胆に Chase your chance はじけよう 理屈なんてどうでもいいから 走れ走れどんなときもありえない向う側へ光 信じて

Try now!

Omoikiri Jumpin' up sakende

Daitan ni chase your chance hajikeyou

Rikutsu nante dou demo ii kara

Hashire hashire donna toki mo arienai mukougawa e hikari shinjite

Try now!

'Lompat dan hempaskan semua

Ayo mulai beranikan dirimu tuk gapai anganmu

Lupakan alasanmu

Larilah larilah, tak peduli kapan, percayalah

pada sinar yang ada di jauh sana

Lakukanlah sekarang!'

Penggalan lirik lagu di atas berisi gaya bahasa alegori karena tidak menjelaskan dengan langsung makna sebenarnya. Makna lirik lagu baris pertama sampai dengan baris ketiga pada bait tersebut berisi ajakan untuk mulai bangkit dan menghapus rasa pesimis dan alasan-alasan lain yang menghambat jalan untuk menggapai cita-cita. Pesimis merupakan suatu hal yang negatif seperti perasaan tidak yakin dan putus asa. Kehidupan yang dijalani dengan perasaan pesimis tidak akan membuat kehidupan tersebut menjadi lebih baik namun hanya akan menyusahkan. Pada baris keempat bait di atas, terdapat kalimat 'percayalah pada sinar yang ada di jauh sana' yang dapat dimaknai dengan teruslah optimis dan berprasangka baik bahwa kebahagiaan atas citacita akan segera didapatkan.

29) 上モダチゾーンくぐり抜けて 急発進 you're so スペシャル

Suddenly で groovin’ ミュージック頭ん中響 $\leq$ all night

Tomodachi zoon kuguri nukete kyuu hasshin you're so supesharu

Suddenly de groovin' myuuikku atama'n naka hibiku all night 
'Mulanya tak ada rasa namun tiba-tiba rasa itu mulai tumbuh dan merekah karena kau begitu spesial

Seketika alunan musik groove terngiang dikepalaku sepanjang malam'

Potongan lirik lagu Chau di atas mengandung gaya bahasa alegori karena tidak menjelaskan makna yang sesungguhnya. Musik groove adalah musik yang dihasilkan dari kesatuan ritme alat musik seperti drum, gitar, piano dan sebagainya. Musik groove merupakan musik yang dikenal dengan musik yang menyenangkan karena temponya, sangat pas dialunkan atau didengarkan saat suasana hati sedang bahagia. Namun pada kalimat 'Seketika alunan musik groove terngiang di kepalaku sepanjang malam',

"musik groove" ialah kata kiasan yang dapat dimaknai dengan perasaan hati yang sedang berbahagia, yang dirasakan sepanjang malam. Hal tersebut disebabkan oleh rasa suka yang kemudian berkembang menjadi cinta, meskipun pada awalnya hanya sebatas teman. Teman yang dimaksud adalah teman yang sering saling bertemu dan saat proses pertemuan itu, secara tidak langsung akan terjadi pengenalan sifat dan karakter satu sama lain. Kalimat penjelasan di atas adalah makna dari 'mulanya tak ada rasa namun tiba-tiba rasa itu mulai tumbuh dan merekah karena kau begitu spesial'.

\section{0) 季節が巡って大人になるほど ほろ苦い愛になってくのかな時計の針が進 んでく度君への思いも強くなる}

\section{Kisetsu ga megutte otona ni naru hodo}

Horo nigai ai ni natteku no kana

Tokei no hari ga susundeku tabi

Kimi e no omoi mo tsuyoku naru

'Musim terus berputar saat kita tumbuh dewasa Apakah ini akan jadi cinta yang pahit?

Setiap kali jarum jam bergerak

Semakin yakin cintaku padamu'

Penggalan lirik lagu di atas memuat gaya bahasa alegori karena tidak menggunakan kata-kata yang memiliki arti sebenarnya. 季節 が巡って kisetsu ga megutte secara harfiah memiliki arti musim yang terus berputar. Makna dari "musim terus berputar" dalam hal ini ialah waktu yang terus berlangsung dengan pergantian musim yaitu musim semi, musim panas, musim gugur dan musim dingin. Keempat musim tersebut merupakan musimmusim yang ada di negara Jepang.

Sama halnya dengan tokoh pada lirik lagu di atas, seseorang yang mengalami dan menyaksikan musim-musim terus berganti sudah pasti usianya semakin bertambah dan tumbuh lebih dewasa. Pada bait sebelumnya telah diceritakan bahwa mereka sudah berpisah namun tokoh Aku masih terus teringat sosok yang dicintainya itu. Meskipun waktu terus berlangsung dan masing-masing tumbuh menjadi dewasa, rasa cintanya semakin kuat. Hal itu disebabkan oleh kesan cinta lalunya yang indah, meskipun telah berpisah akan selalu dikenang.

\section{1) おもいきり転べば泣きたくもなるけど 空を見上げ我慢 勝利の秘訣さ}

\section{Omoikiri korobeba nakitaku mo naru kedo \\ Sora o miage gaman shouri no hiketsu sa}

\section{'Saat terjatuh, serpihan-serpihan air mata pun} menetes

Menatap langit berserah tuk hapus air mata ini' Menggunakan kata-kata kiasan untuk merangkai kalimat merupakan ciri dari gaya bahasa alegori seperti bait dalam lirik lagu Kirakira Hikare di atas. Lagu ini merupakan lagu yang mengandung pesan penyemangat untuk orang-orang di sekitarnya. Kalimat "Saat terjatuh, serpihan-serpihan air mata pun menetes" mempunyai makna saat dalam keterpurukan, hati akan merasakan sedih. Rasa sedih yang meluap adalah pemicu menetesnya air mata. Untuk menghapus rasa sedih itu, maka "menatap langit berserah" yaitu berdoa pada Sang Pencipta dan merelakan akan apa yang sudah terjadi.

\section{Gaya Bahasa Eponim}

32) キラキラもっと光れ 魔法にもっとかかれ 夢を見る子供たちが増えればもつとドキドキ もっとしちゃえ 夢中でもつと走れ幸せな笑顔 が咲く未来が来るよ

Kira kira motto hikare mahou ni motto kakare Yume o miru kodomotachi ga fuereba motto Doki doki motto shichae muchuu de motto hashire Shiawase na egao ga saku mirai ga kuru yo

'Bersinarlah lebih berkilau katakan lagi mantra sihir 
Bila lebih banyak anak-anak yang jadi pemimpi Biarkan hati berdegup kencang dan larilah lebih bersemangat dalam mimpi

Senyum bahagia akan bermekaran'

Kalimat di atas dikategorikan sebagai gaya bahasa eponim karena menggunakan kata atau nama yang sering dihubungkan untuk menggambarkan suatu sifat tertentu. Eponim pada lirik lagu Kira-kira Hikare menyebut kata "pemimpi" yang terdapat pada kalimat baris kedua bait keempat. Kata "pemimpi" merujuk pada makna anak-anak yang mempunyai citacita dan akan berusaha untuk menggapainya. Pepatah menyebutkan usaha tidak akan mengkhianati hasil. Maka dengan usaha yang lebih giat dan semangat yang dilakukan, kesuksesan dapat diraih.

\section{Gaya Bahasa Sinekdoke}

\section{3) 季節が巡って大人になるほど ほろ苦い愛になってくのかな時計の針が進 んでく度君への思いも強くなる}

Kisetsu ga megutte otona ni naru hodo

Horo nigai ai ni natteku no kana

Tokei no hari ga susundeku tabi

Kimi e no omoi mo tsuyoku naru

'Musim terus berputar saat kita tumbuh dewasa Apakah ini akan jadi cinta yang pahit?

Setiap kali jarum jam bergerak

Semakin yakin cintaku padamu'

Bait dalam lirik lagu di atas memuat gaya bahasa sinekdoke pars pro toto karena menyebutkan sebagian untuk menjelaskan keseluruhan. Gaya bahasa sinekdoke pars pro toto terdapat pada kata 季節 kisetsu "musim".

Musim adalah peristiwa pembagian waktu yang terjadi berdasarkan iklim di atmosfer. Wilayah Jepang memiliki pembagian empat musim setiap tahunnya yaitu musim semi, musim panas, musim gugur dan musim dingin yang mana musim-musim tersebut diwakili oleh kata "musim" pada lirik lagu tersebut. Setiap musim memiliki ciri khas yang berbeda seperti musim semi yang mempunyai ciri khas bunga-bunga yang bermekaran, musim panas yang memiliki panas matahari yang sangat terik disepanjang waktunya, musim gugur yang ditandai dengan gaun-daun yang berguguran serta seringnya terjadi hujan, dan musim dingin merupakan musim dengan suhu paling dingin di bumi yang menyebabkan turunnya salju.

\section{Gaya Bahasa Metonimia}

34) ちゅう もっとコッチ見てよ ちゅうちつちゃな 僕だけどさみしくさせない ちゆうちゅう

Chuu motto kocchi mite yo Chuu

Chiccha na boku dakedo samishiku sasenai chuu chuu

'Chuu mendekatlah chuu

Aku memang kecil namun aku tidak akan membiarkanmu kesepian chuu chuu'

Bait pertama lagu Pet Shop Love Motion mengandung unsur gaya bahasa metonimia yang membandingkan suatu kata dengan kata lainnya yang lebih dikenal.

Pada lirik lagu tersebut gaya bahasa metonimia terdapat pada kata "Chuu". "Chuu" adalah salah satu bentuk dari onomatopoeia. Onomatopoeia adalah suara yang mewakili kata. Dalam bahasa Jepang, onomatopoeia memiliki beberapa kategori seperti suara manusia dan hewan, perasaan, dan sebagainya.

Dalam hal ini kata "chuu" merepresentasikan suara hewan, yaitu marmut. Marmut adalah hewan peliharaan manusia yang sangat disukai karena sifatnya yang lucu dan ukurannya sangat kecil. Seperti yang sudah diungkapkan pada lirik lagu di atas, memelihara hewan peliharaan seperti marmut dapat bermanfaat untuk menghilangkan rasa stress dan kesepian bagi manusia.

\section{5) にやあ 僕の方見てよ にやあ気分屋な僕は 甘え上手ですにやあにやあ}

Nyaa boku no hou mite yo nyaa

Kibunya na boku wa amae jouzu desu nyaa nyaa

'Nyaa lihatlah aku nyaa

Aku memang moody namun aku mudah dimanja'

Penggunaan gaya bahasa metonimia juga terdapat pada bait kedua lagu Pet shop love motion. Kata "nyaa" menunjukkan gaya bahasa metonimia yang menggantikan suatu kata yang sejajar atau lebih dikenal dengan kata lainnya. Kata tersebut juga termasuk dalam onomatopoeia yang mempresentasikan suara hewan yaitu kucing. Kucing adalah hewan berbulu dengan empat kaki yang banyak dipelihara oleh manusia untuk menghilangkan stress dan meningkatkan suasana hati menjadi lebih baik. 
36) ぴょん 見つめ返してよ ぴょんさみしがりや な僕にギュッとしてほしい ぴょんぴょん

Pyon mitsume kaeshite yo pyon

Samishigariya na boku ni gyutto shite hoshii pyon pyon

'Pyon kembalilah tatap aku pyon

Aku yang kesepian ini ingin dibawa pyon pyon' Penggalan lirik lagu di atas mengandung gaya bahasa metonimia karena terdapat unsur yang mendukungnya, yaitu mengungkapkan sesuatu menggunakan kata lain yang berkaitan sebagai penggantinya. Gaya bahasa metonimia dalam lirik lagu di atas terdapat pada kata onomatopoeia yang berasal dari suara hewan dan dalam bahasa Jepang disebut 擬声語 giseigo. "Pyon" termasuk dalam onomatopoeia dari kelinci. Onomatopoeia dalam cerita tersebut mendeskripsikan kelinci yang melompat-lompat, menarik perhatian pengunjung yang datang.

37) わん どーせ俺なんて誰も見ちやあいねーし でも俺じやダメですかわんわん

Wan douse ore nante wan dare mo miccha aeneshi Demo ore ja dame desu ka wanwan

'Wan mengapa tak ada yang melihatku Apakah aku tidak menarik wan wan'

Gaya bahasa metonimia yang termuat dalam lirik lagu di atas adalah gaya bahasa yang digunakan untuk mengungkapkan suatu hal dengan kata lain yang mempunyai sifat yang sama. Dalam hal ini, kata yang mengandung metonimia terdapat pada kata "wan" yang merupakan onomatopoeia dari anjing. Anjing merupakan salah satu hewan peliharaan yang banyak disukai oleh manusia karena tingkahnya yang menggemaskan dan bermanfaat untuk menghilangkan rasa penat dan kesepian.

\section{Gaya Bahasa Epitet}

38) 恋は、キラリミステリー 最高に刺激的なクエ スチョン

今夜君とロマンスタイム宇宙一熱いキスクイ ニン\&ナイト

Koi wa kirari misuterii saikou ni shigekitekina kuesuchon

Konya kimi to romansu taimu uchuu ichi atsui kisu kuiin \& naito
'Cinta adalah misteri yang berkilau, rahasia terindah penuh sensasi

Malam ini bercinta denganmu, kecupan sang ratu dan ksatria yang paling bergairah di semesta'

Potongan lirik lagu Weekender di atas mengandung gaya bahasa epitet. Penggunaan gaya bahasa epitet menyebutkan sesuatu tidak dengan nama aslinya melainkan dengan salah satu sifat atau ciri khusus hal tersebut. Kata yang merupakan gaya bahasa epitet pada kalimat tersebut yaitu クイーン\&ナイト kuiin \& naito 'Ratu dan ksatria'. Makna lirik lagu di atas menceritakan seorang pria dan wanita yang saling jatuh cinta, baru saja menjadi sepasang kekasih. Ada sebagian orang yang sedang jatuh cinta tidak akan peduli dengan keadaan sekitarnya, di pikirannya hanya ada tentang mereka sama halnya dengan cerita lirik lagu di atas yang menganggap dirinya adalah ratu dan ksatria yang sedang jatuh cinta.

\section{Gaya Bahasa Antonomasia}

39) ダメだよユア・マイ Puppy Boo 見えなくなる ほど離れちゃ

優しい首輪みたいに 手を繋いじゃうぞ

Dame da yo yua mai Puppy Boo mienakunaru hodo hanarecha

Yasashii kubiwa mitaini te o tsunaijauzo

'Kaulah puppy boo ku, jangan pergi jauh dari pandanganku

Seperti rantai lembut yang akan menuntunmu'

Kata "Puppy boo" yang terdapat pada lirik lagu di atas adalah kata yang digunakan sebagai panggilan nama kesayangan. Untuk membuat hubungan lebih dekat tidak jarang masing-masing pasangan mempunyai panggilan kesayangan yang khas. Sama halnya dengan cerita lirik lagu di atas, menyebutkan nama kekasih dengan panggilan sayang "Puppy Boo". Hal tersebut menunjukkan gaya bahasa antonomasia. Lirik lagu di atas menceritakan seseorang yang melarang pasangannya pergi meninggalkannya dan untuk mencegah hal itu, Ia akan terus menjaga dan membahagiakannya.

10. Gaya Bahasa Sinisme

40)まだ終わらないの? That's your work 手伝 わないけど 


\section{送ってやろうか? 待っててやるから 余計ドタ バタ Pretty Girl}

Mada owaranai no? That's your work tetsudawanai kedo

Okutteyarou ka? Mattete yaru kara yokei dotabata Pretty Girl

'Belum selesaikah? Itu pekerjaanmu aku tidak akan membantu

Haruskah aku mengantarmu pulang? Aku akan menunggumu wanita cantikku yang sibuk'

Penggalan lirik lagu Puppy Boo di atas memuat gaya bahasa sinisme. Gaya bahasa sinisme merupakan gaya bahasa yang mengungkapkan sindiran secara langsung. Pada lirik lagu tersebut diceritakan peristiwa seseorang yang menghampiri kekasihnya untuk cepat-cepat mengajaknya pulang dengan tujuan agar bisa menikmati waktu berdua. Lalu menyadari bahwa kekasihnya tidak akan pulang segera, dan berinisiatif untuk menunggu. Namun sindiran terucap kepada kekasihnya pada kalimat 'Aku akan menunggumu wanita cantikku yang sibuk'.

\section{Gaya Bahasa Sarkasme}

41) がんばり屋なのは Yes, I know 口にしない けど

無茶苦茶しないで 倒れたら困る 君よりも僕 がさ

Ganbariya na no wa yes, i know kuchi ni shinai kedo Muchakucha shinaide taoretara komaru kimi yori mo boku ga sa

'Kau slalu bekerja keras, ya aku tahu, hanya saja ku tak pernah mengatakannya Jangan kau paksakan, atau aku kan jadi sulit bila kau jatuh pingsan'

Sindiran pada gaya bahasa sarkasme lebih menyakitkan daripada sindiran pada gaya bahasa ironi dan sinisme. Sarkasme mudah ditemukan pada percakapan sehari-hari. Gaya bahasa sarkasme pada lirik lagu di atas ditunjukkan pada kalimat 'jangan kau paksa, atau aku kan jadi sulit bila kau jatuh pingsan'. Maksud dari kalimat 'jangan kau paksa, atau aku kan jadi sulit bila kau jatuh pingsan' adalah melarang terlalu memforsir diri untuk bekerja, apabila jatuh pingsan akibat bekerja akan merepotkan merepotkan orang lain.

\section{KESIMPULAN}

Penelitian ini menggunakan teori gaya bahasa menurut Keraf. Berdasarkan teori Keraf, gaya bahasa terdiri dari gaya bahasa metafora, gaya bahasa personifikasi, gaya bahasa simile, gaya bahasa alegori, gaya bahasa alusi, gaya bahasa eponim, gaya bahasa sinekdoke, gaya bahasa metonimia, gaya bahasa epitet, gaya bahasa antonomasia, gaya bahasa hipalase, gaya bahasa sinisme dan sarkasme, gaya bahasa satire, gaya bahasa inuendo, gaya bahasa antifrasis, dan gaya bahasa paronomasia.

Namun pada sumber data hanya ditemukan 11 (sebelas) gaya bahasa yaitu 3 (tiga) data gaya bahasa metafora, 5 (lima) data gaya bahasa personifikasi, 7 (tujuh) data gaya bahasa simile, 16 (enam belas) data gaya bahasa alegori, 1 (satu) data gaya bahasa eponim, 1 (satu) data gaya bahasa sinekdoke, 4 (empat) data gaya bahasa metonimia, 1 (satu) gaya bahasa epitet, 1 (satu) gaya bahasa antonomasia, 1 (satu) gaya bahasa sinisme dan 1 (satu) gaya bahasa sarkasme. Berdasarkan gaya bahasa yang ditemukan, gaya bahasa yang terbanyak adalah gaya bahasa alegori.

Keseluruhan makna dari gaya bahasa yang ditemukan menunjukkan bahwa lagu-lagu dalam album Jumping Car menggambarkan kisah cinta dan kehidupan yang di dalamnya mengandung kebahagiaan dan kesedihan.

Berikut adalah daftar tabel hasil analisis gaya bahasa kiasan yang terdapat pada 12 (dua belas) lirik lagu Hey! Say! Jump pada album Jumping Car.

\section{DAFTAR PUSTAKA}

Aminuddin. 1995. Stilistika Pengantar Memahami Bahasa dalam Karya Sastra.

Semarang: IKIP Semarang Press.

Azzahroh, Asma. 2016. Skripsi. Gaya Bahasa Pada Lirik Lagu Sawai Miku

dalam Album Yuuutsu Biyori. Jurusan Sastra

Jepang Universitas

Jenderal Soedirman: Purwokerto.

Black, Elizabeth. 2011. Stilistika Pragmatis. Yogyakarta: Pustaka Pelajar. 
Keraf, Gorys. 1997. Komposisi. Flores: Nusa Indah.

Keraf, Gorys. 2009. Diksi dan Gaya Bahasa. Jakarta: PT Gramedia Pustaka Utama.

Koentjaraningrat. 1986. Pengantar Ilmu Antropologi. Jakarta: Aksara Baru.

Kridalaksana, Harimurti. 2009. Kamus Linguistik. Jakarta: PT Gramedia Pustaka Utama.

Moleong, Lexy J. 2015. Metode Penelitian Kualitatif. Bandung: PT Remaja Rosdakarya.

Prasetyo, Tri. 2016. Skripsi. Analisis Gaya Bahasa Teks Lagu Karya Grup Band Payung Teduh dalam Album 'Payung Teduh' dan 'Dunia Batas'. Jurusan Bahasa dan Sastra Indonesia

Universitas Jenderal Soedirman: Purwokerto.

Ratna, Nyoman Kutha. 2016. Stilistika Kajian

Puitika Bahasa, Sastra, dan Budaya. Yogyakarta: Pustaka Pelajar.

Sudaryanto. 2015. Metode dan Aneka Teknik Analisis Bahasa. Yogyakarta:

Santa Dharma University Press.

Sutedi, Dedi. 2014. Dasar-Dasar Linguistik Bahasa Jepang. Bandung: Humaniora.

Taniguchi, Goro. 2004. Kamus Standar Bahasa Jepang Indonesia. Jakarta:

Dian Rakyat.

Ulmann, Stephen. 2007. Pengantar Semantik. Yogyakarta: Pustaka Pelajar.

Widodo, Tri. 2016. Skripsi. Memahami Gaya Bahasa Lima Lirik Lagu Pada Album Hidup Lebih Indah Karya D'Masiv. Jurusan Bahasa dan

Sastra Indonesia Universitas Jenderal Soedirman: Purwokerto.
Oricon News. 2015. Hey! Say! Jump! Jumping

Car Album. https://www.oricon.co.jp/prof/437772/pro ducts $/ 1133418 / 1 /$. Akses Juli 2017.

Serpent Sanctum. 2017. Benzaiten: White Snake Goddess of Japan. http://serpentsanctum.com/benzaitenwhite-snake-goddess-of-japan/. Akses Agustus 2019.

Tofugu. 2015. Japanese Onomatopoeia: The Definitive Guide. https://www.tofugu.com/japanese/japanes e-onomatopoeia/. Akses Juli 2019.

\section{PUSTAKA LAMAN}

Badan Pengembangan dan Pembinaan Bahasa. 2016. Kamus Besar Bahasa Indonesia.

https://kbbi.kemdikbud.go.id/entri/lirik.

Akses Februari 2018.

Libgar. 2018. Eros Mitologi Yunani. https://www.libgar.com/2018/01/eros2019. mitologi-yunani.html. Akses Agustus 